\title{
The Pandemic Pestilences and Internet Institutes
}

\section{Kuo-Chen Chou}

Gordon Life Science Institute, Boston, Massachusetts 02478, United States of America

Correspondence to: Kuo-Chen Chou, kcchou@gordonlifescience.org, kcchou38@gmail.com

Keywords: Pandemic COVID-19, Pestilences, Atheists, Christians, Internet Institutes

Received: July 4, $2020 \quad$ Accepted: July 12, $2020 \quad$ Published: July 15, 2020

Copyright $\odot 2020$ by author(s) and Scientific Research Publishing Inc.

This work is licensed under the Creative Commons Attribution International License (CC BY 4.0).

http://creativecommons.org/licenses/by/4.0/

\section{Open Access}

\section{ABSTRACT}

Whether the recent "Pandemic Pestilences" are of clear sign for the "World End"? Both "Atheists" and "Christians" have deeply believed so. During such a subtle time-period, many exciting results can be produced by the Internet Institutes.

\section{INTRODUCTION}

As of July-06-2020, about 200 countries on the Earth have been attacked by Pestilences 2019 (COVID-19): for USA that consists of 50 states, 48 states have been identified with "Pestilences". The total number of the cases concerned is $2,803,454$ of which 130,995 result in deaths. For United Kingdom, the corresponding numbers are 283,757 and 43,995 , respectively.

\section{FACTS AND DISCUSSIONS}

It is much more powerful than the "Atomic Bomb" detonated over Japanese city of Hiroshima on August 6, 1945. The bombing killed 129,000 people.

It is also much more horrified than the Terrorists Attack on September 11, 2001 (often referred to "911"). The attacks resulted in 2977 fatalities, over 25,000 injuries, and substantial long-term health consequences.

The number of deaths caused by Pestilences has also significantly exceeded that of military persons killed in any of war involved with USA.

For the so-called "Atheists", typically represented by "Karl Max" and "Friedrich Engels", have written in their books: "there is a Beginning, there must be an End", clearly stating: "the Earth will eventually disappear owing to colliding with the other planet".

According to Bible, however, close to the "World-End", nation will rise against nation, and kingdom against kingdom. There will be great earthquakes, famines and pestilences in various places, and fearful events and great signs from Heaven.

Even in the Pachelbel tune that has been played most frequently and constantly, some female singers ask God the two questions: "Why"? and "When"? The $1^{\text {st }}$ question is about "why there is the End of World" while the $2^{\text {nd }}$ question is about "when it will come true". 
Right before the World-End, Jesus will send out his angels to weed out those who are sin, evil and wicked. They will be thrown by the angels into the fiery furnace, where they will be weeping and gnashing of teeth. In contrast to this, the righteous will be raised to the Heaven.

Pestilences or Coronavirus disease 2019 (COVID-19) is an infectious disease caused by severe acute respiratory syndrome, which was first identified in December 2019 in Wuhan, Hubei, China. After April 2020 and causing about 4000 deaths, although no remarkable infectious cases reported in Wuhan. Nevertheless and unfortunately, the $2^{\text {nd }}$-wave coronavirus diseases have been also identified on Beijing during May 2020. This kind of originally from "East-Globe" or "Eastern hemisphere" to "West "Globe" or "Western Hemisphere" and then kicked back from the West to the East again, very much like playing "Tennis", "Ping-Pong" or "Badminton", "Ball". The extremely dangerous Ball is none but "Coronavirus" or "Pestilences".

Since all the scientists working in a sharing laboratory of the Universities or most conversional Institutes must wear masks except those working in the "Internet Institute" (Figure 1) such as the "Gordon Life Scient Institute" [1,2]. And the results thus obtained will be of real usage for the other planet as indicated in [3] as well as widely and increasingly agreeable as supported by many papers from different angles or aspects, particularly for the idea of "Pseudo Amino Acid Composition" or PseAAC" [4-74], the "5-steps Rule" [75-97], the "Wenxiang Diagram" [98-100], the "HIV protease inhibitor prediction" [101-106], and the "Graphic Rules" [107-115]. Using graphic approaches to study biological and medical systems can provide an intuitive vision and useful insights for helping analyze complicated relations therein as shown by the eight master pieces of pioneering papers from the then Chairman of Nobel Prize Committee Sture Forsen [107, 109, 110, 116-120] and many follow-up papers [67, 98, 99, 113, 115, 121-163], and a series of recent papers [164-180].

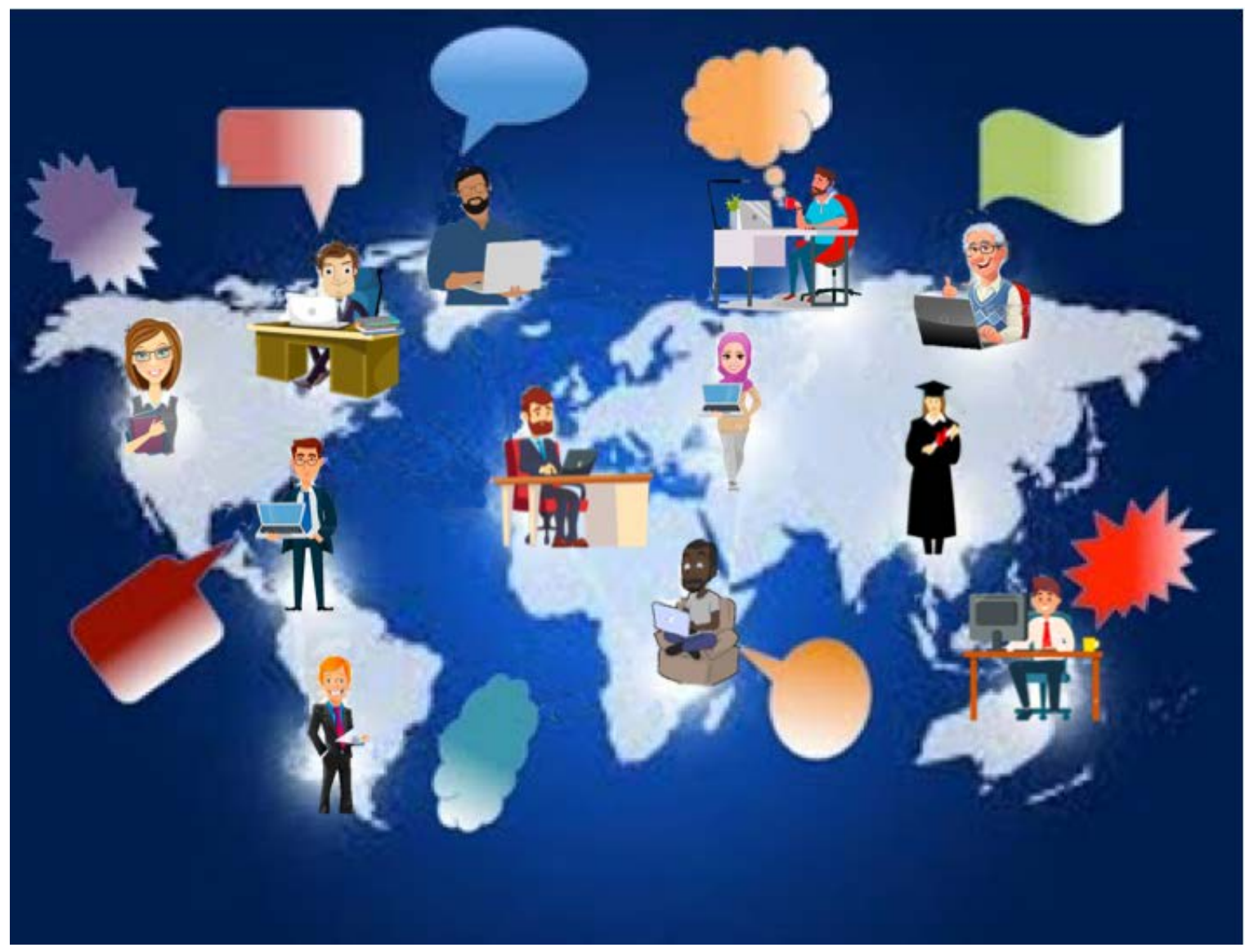

Figure 1. A schematic drawing to show how the Internet Institutes work. 
Moreover, it is instructive to point out that, based on the works on protein conformation [181-196], the new classifications for protein structures have been developed [102, 105, 106, 143, 197-207], that based on the works of low-frequency internal motions [116, 121, 122, 124-132, 134, 208], that based on the works on the graphical rules for biological systems [108-115, 136, 209, 210], that based on the works on enzyme kinetics $[108,111-114,119,136,209,211-232]$, that based on the works on HIV proteases [101, 102, 104, 106, 233-238], that Post-translational modification (PTM) [239-270], and that protein subcellular location prediction [162, 268, 271-288].

\section{CONCLUSIONS}

For our Earth, after several waves of the killings as described in the Section 2, the time of its "End" will become much faster according to the exponential mode. Before its "End", it will provide the most useful knowledge to do the science with the "Internet Institutes."

\section{CONFLICTS OF INTEREST}

The authors declare no conflicts of interest regarding the publication of this paper.

\section{REFERENCES}

1. Chou, K.C. (2019) The Cradle of Gordon Life Science Institute and Its Development and Driving Force. Biomedical Journal of Scientific \& Technical Research, 23, Article ID: 17848.

2. Chou, K.C. (2019) Intriguing Story about the Birth of Gordon Life Science Institute and Its Development and Driving Force. Journal of Retro Virology and Anti Retro Virology, 1, Article ID: 180002.

3. Chou, K.C. (2020) The Development of Gordon Life Science Institute: Its Driving Force and Accomplishments. Natural Science, 12, 202-217. https://doi.org/10.4236/ns.2020.124018

4. Hayat, M. and Khan, A. (2012) Discriminating Outer Membrane Proteins with Fuzzy K-Nearest Neighbor Algorithms Based on the General Form of Chou's PseAAC. Protein \& Peptide Letters, 19, 411-421. https://doi.org/10.2174/092986612799789387

5. Liao, B., Xiang, Q. and Li, D. (2012) Incorporating Secondary Features into the General form of Chou's PseAAC for Predicting Protein Structural Class. Protein \& Peptide Letters, 19, 1133-1138. https://doi.org/10.2174/092986612803217051

6. Mei, S. (2012) Multi-Kernel Transfer Learning Based on Chou's PseAAC Formulation for Protein Submitochondria Localization. Journal of Theoretical Biology, 293, 121-130. https://doi.org/10.1016/j.jtbi.2011.10.015

7. Mei, S. (2012) Predicting Plant Protein Subcellular Multi-Localization by Chou's PseAAC Formulation Based Multi-Label Homolog Knowledge Transfer Learning. Journal of Theoretical Biology, 310, 80-87. https://doi.org/10.1016/j.jtbi.2012.06.028

8. Qin, Y.F., Wang, C.H., Yu, X.Q., Zhu, J., Liu, T.G. and Zheng, X.Q. (2012) Predicting Protein Structural Class by Incorporating Patterns of Over-Represented k-mers into the General form of Chou's PseAAC. Protein \& Peptide Letters, 19, 388-397. https://doi.org/10.2174/092986612799789350

9. Sun, X.Y., Shi, S.P., Qiu, J.D., Suo, S.B., Huang, S.Y. and Liang, R.P. (2012) Identifying Protein Quaternary Structural Attributes by Incorporating Physicochemical Properties into the General Form of Chou's PseAAC via Discrete Wavelet Transform. Molecular BioSystems, 8, 3178-3184. https://doi.org/10.1039/c2mb25280e

10. Cao, D.S., Xu, Q.S. and Liang, Y.Z. (2013) propy: A Tool to Generate Various Modes of Chou's PseAAC. Bioinformatics, 29, 960-962. https://doi.org/10.1093/bioinformatics/btt072

11. Chang, T.H., Wu, L.C., Lee, T.Y., Chen, S.P., Huang, H.D. and Horng, J.T. (2013) EuLoc: A Web-Server for Accurately Predict Protein Subcellular Localization in Eukaryotes by Incorporating Various Features of Se- 
quence Segments into the General Form of Chou's PseAAC. Journal of Computer-Aided Molecular Design, 27, 91-103. https://doi.org/10.1007/s10822-012-9628-0

12. Fan, G.-L., Li, Q.-Z. and Zuo, Y.-C. (2013) Predicting Acidic and Alkaline Enzymes by Incorporating the Average Chemical Shift and Gene Ontology Informations into the General Form of Chou's PseAAC. Process Biochemistry, 48, 1048-1053. https://doi.org/10.1016/j.procbio.2013.05.012

13. Pacharawongsakda, E. and Theeramunkong, T. (2013) Predict Subcellular Locations of Singleplex and Multiplex Proteins by Semi-Supervised Learning and Dimension-Reducing General Mode of Chou's PseAAC. IEEE Transactions on Nanobioscience, 12, 311-320. https://doi.org/10.1109/TNB.2013.2272014

14. Xie, H.L., Fu, L. and Nie, X.D. (2013) Using Ensemble SVM to Identify Human GPCRs N-Linked Glycosylation Sites Based on the General Form of Chou's PseAAC. Protein Engineering, Design and Selection, 26, 735-742. https://doi.org/10.1093/protein/gzt042

15. Han, G.S., Yu, Z.G. and Anh, V. (2014) A Two-Stage SVM Method to Predict Membrane Protein Types by Incorporating Amino Acid Classifications and Physicochemical Properties into a General Form of Chou's PseAAC. Journal of Theoretical Biology, 344, 31-39. https://doi.org/10.1016/j.jtbi.2013.11.017

16. Li, L., Yu, S., Xiao, W., Li, Y., Li, M., Huang, L., Zheng, X., Zhou, S. and Yang, H. (2014) Prediction of Bacterial Protein Subcellular Localization by Incorporating Various Features into Chou's PseAAC and a Backward Feature Selection Approach. Biochimie, 104, 100-107. https://doi.org/10.1016/j.biochi.2014.06.001

17. Zhang, J., Zhao, X., Sun, P. and Ma, Z. (2014) PSNO: Predicting Cysteine S-Nitrosylation Sites by Incorporating Various Sequence-Derived Features into the General Form of Chou's PseAAC. International Journal of Molecular Sciences, 15, 11204-11219. https://doi.org/10.3390/ijms150711204

18. Liu, B., Xu, J., Fan, S., Xu, R., Zhou, J. and Wang, X. (2015) PseDNA-Pro: DNA-Binding Protein Identification by Combining Chou's PseAAC and Physicochemical Distance Transformation. Molecular Informatics, 34, 8-17. https://doi.org/10.1002/minf.201400025

19. Mandal, M., Mukhopadhyay, A. and Maulik, U. (2015) Prediction of Protein Subcellular Localization by Incorporating Multiobjective PSO-Based Feature Subset Selection into the General Form of Chou's PseAAC. Medical \& Biological Engineering \& Computing, 53, 331-344. https://doi.org/10.1007/s11517-014-1238-7

20. Sanchez, V., Peinado, A.M., Perez-Cordoba, J.L. and Gomez, A.M. (2015) A New Signal Characterization and Signal-Based Chou's PseAAC Representation of Protein Sequences. Journal of Bioinformatics and Computational Biology, 13, Article ID: 1550024. https://doi.org/10.1142/S0219720015500249

21. Kabir, M. and Hayat, M. (2016) iRSpot-GAEnsC: Identifying Recombination Spots via Ensemble Classifier and Extending the Concept of Chou's PseAAC to Formulate DNA Samples. Molecular Genetics and Genomics, 291, 285-296. https://doi.org/10.1007/s00438-015-1108-5

22. Tahir, M. and Hayat, M. (2016) iNuc-STNC: A Sequence-Based Predictor for Identification of Nucleosome Positioning in Genomes by Extending the Concept of SAAC and Chou's PseAAC. Molecular BioSystems, 12, 2587-2593. https://doi.org/10.1039/C6MB00221H

23. Ju, Z. and He, J.J. (2017) Prediction of Lysine Propionylation Sites Using Biased SVM and Incorporating Four Different Sequence Features into Chou's PseAAC. Journal of Molecular Graphics and Modelling, 76, 356-363. https://doi.org/10.1016/j.jmgm.2017.07.022

24. Yu, B., Li, S., Qiu, W.Y., Chen, C., Chen, R.X., Wang, L., Wang, M.H. and Zhang, Y. (2017) Accurate Prediction of Subcellular Location of Apoptosis Proteins Combining Chou's PseAAC and PsePSSM Based on Wavelet Denoising. Oncotarget, 8, 107640-107665. https://doi.org/10.18632/oncotarget.22585

25. Ahmad, J. and Hayat, M. (2018) MFSC: Multi-Voting Based Feature Selection for Classification of Golgi Proteins by Adopting the General Form of Chou's PseAAC Components. Journal of Theoretical Biology, 463, 99-109. https://doi.org/10.1016/j.jtbi.2018.12.017 
26. Akbar, S. and Hayat, M. (2018) iMethyl-STTNC: Identification of $\mathrm{N}^{6}$-Methyladenosine Sites by Extending the Idea of SAAC into Chou's PseAAC to Formulate RNA Sequences. Journal of Theoretical Biology, 455, 205-211. https://doi.org/10.1016/j.jtbi.2018.07.018

27. Contreras-Torres, E. (2018) Predicting Structural Classes of Proteins by Incorporating Their Global and Local Physicochemical and Conformational Properties into General Chou's PseAAC. Journal of Theoretical Biology, 454, 139-145. https://doi.org/10.1016/j.jtbi.2018.05.033

28. Fu, X., Zhu, W., Liso, B., Cai, L., Peng, L. and Yang, J. (2018) Improved DNA-Binding Protein Identification by Incorporating Evolutionary Information into the Chou's PseAAC. IEEE Access, 6, 66545-66556. https://doi.org/10.1109/ACCESS.2018.2876656

29. Javed, F. and Hayat, M. (2018) Predicting Subcellular Localizations of Multi-Label Proteins by Incorporating the Sequence Features into Chou's PseAAC. Genomics, 111, 1325-1332. https://doi.org/10.1016/j.ygeno.2018.09.004

30. Mousavizadegan, M. and Mohabatkar, H. (2018) Computational Prediction of Antifungal Peptides via Chou's PseAAC and SVM. Journal of Bioinformatics and Computational Biology, 16, Article ID: 1850016. https://doi.org/10.1142/S0219720018500166

31. Zhang, S. and Liang, Y. (2018) Predicting Apoptosis Protein Subcellular Localization by Integrating Auto-Cross Correlation and PSSM into Chou's PseAAC. Journal of Theoretical Biology, 457, 163-169.

https://doi.org/10.1016/j.jtbi.2018.08.042

32. Ahmad, J. and Hayat, M. (2019) MFSC: Multi-Voting Based Feature Selection for Classification of Golgi Proteins by Adopting the General Form of Chou's PseAAC Components. Journal of Theoretical Biology, 463, 99-109. https://doi.org/10.1016/j.jtbi.2018.12.017

33. Butt, A.H., Rasool, N. and Khan, Y.D. (2019) Prediction of Antioxidant Proteins by Incorporating Statistical Moments Based Features into Chou's PseAAC. Journal of Theoretical Biology, 473, 1-8. https://doi.org/10.1016/j.jtbi.2019.04.019

34. Javed, F. and Hayat, M. (2019) Predicting Subcellular Localization of Multi-Label Proteins by Incorporating the Sequence Features into Chou's PseAAC. Genomics, 111, 1325-1332. https://doi.org/10.1016/j.ygeno.2018.09.004

35. Tahir, M., Hayat, M. and Khan, S.A. (2019) iNuc-ext-PseTNC: An Efficient Ensemble Model for Identification of Nucleosome Positioning by Extending the Concept of Chou's PseAAC to Pseudo-Tri-Nucleotide Composition. Molecular Genetics and Genomics, 294, 199-210. https://doi.org/10.1007/s00438-018-1498-2

36. Hayat, M. and Iqbal, N. (2014) Discriminating Protein Structure Classes by Incorporating Pseudo Average Chemical Shift to Chou's General PseAAC and Support Vector Machine. Computer Methods and Programs in Biomedicine, 116, 184-192. https://doi.org/10.1016/j.cmpb.2014.06.007

37. Ahmad, S., Kabir, M. and Hayat, M. (2015) Identification of Heat Shock Protein Families and J-Protein Types by Incorporating Dipeptide Composition into Chou's General PseAAC. Computer Methods and Programs in Biomedicine, 122, 165-174. https://doi.org/10.1016/j.cmpb.2015.07.005

38. Dehzangi, A., Heffernan, R., Sharma, A., Lyons, J., Paliwal, K. and Sattar, A. (2015) Gram-Positive and Gram-Negative Protein Subcellular Localization by Incorporating Evolutionary-Based Descriptors into Chou's General PseAAC. Journal of Theoretical Biology, 364, 284-294. https://doi.org/10.1016/j.jtbi.2014.09.029

39. Sharma, R., Dehzangi, A., Lyons, J., Paliwal, K., Tsunoda, T. and Sharma, A. (2015) Predict Gram-Positive and Gram-Negative Subcellular Localization via Incorporating Evolutionary Information and Physicochemical Features Into Chou's General PseAAC. IEEE Transactions on NanoBioscience, 14, 915-926.

https://doi.org/10.1109/TNB.2015.2500186

40. Zhang, M., Zhao, B. and Liu, X. (2015) Predicting Industrial Polymer Melt Index via Incorporating Chaotic Characters into Chou's General PseAAC. Chemometrics and Intelligent Laboratory Systems, 146, 232-240. https://doi.org/10.1016/j.chemolab.2015.05.028 
41. Zhang, S.L. (2015) Accurate Prediction of Protein Structural Classes by Incorporating PSSS and PSSM into Chou's General PseAAC. Chemometrics and Intelligent Laboratory Systems, 142, 28-35. https://doi.org/10.1016/j.chemolab.2015.01.004

42. Ahmad, K., Waris, M. and Hayat, M. (2016) Prediction of Protein Submitochondrial Locations by Incorporating Dipeptide Composition into Chou's General Pseudo Amino Acid Composition. The Journal of Membrane Biology, 249, 293-304. https://doi.org/10.1007/s00232-015-9868-8

43. Behbahani, M., Mohabatkar, H. and Nosrati, M. (2016) Analysis and Comparison of Lignin Peroxidases between Fungi and Bacteria Using Three Different Modes of Chou's General Pseudo Amino Acid Composition. Journal of Theoretical Biology, 411, 1-5. https://doi.org/10.1016/j.jtbi.2016.09.001

44. Fan, G.L., Liu, Y.L. and Wang, H. (2016) Identification of Thermophilic Proteins by Incorporating Evolutionary and Acid Dissociation Information into Chou's General Pseudo Amino Acid Composition. Journal of Theoretical Biology, 407, 138-142. https://doi.org/10.1016/j.jtbi.2016.07.010

45. Ju, Z., Cao, J.Z. and Gu, H. (2016) Predicting Lysine Phosphoglycerylation with Fuzzy SVM by Incorporating k-Spaced Amino Acid Pairs into Chou's General PseAAC. Journal of Theoretical Biology, 397, 145-150. https://doi.org/10.1016/j.jtbi.2016.02.020

46. Tiwari, A.K. (2016) Prediction of G-Protein Coupled Receptors and Their Subfamilies by Incorporating Various Sequence Features into Chou's General PseAAC. Computer Methods and Programs in Biomedicine, 134, 197-213. https://doi.org/10.1016/j.cmpb.2016.07.004

47. Xu, C., Sun, D., Liu, S. and Zhang, Y. (2016) Protein Sequence Analysis by Incorporating Modified Chaos Game and Physicochemical Properties into Chou's General Pseudo Amino Acid Composition. Journal of Theoretical Biology, 406, 105-115. https://doi.org/10.1016/j.jtbi.2016.06.034

48. Zou, H.L. and Xiao, X. (2016) Classifying Multifunctional Enzymes by Incorporating Three Different Models into Chou's General Pseudo Amino Acid Composition. The Journal of Membrane Biology, 249, 551-557. https://doi.org/10.1007/s00232-016-9904-3

49. Jiao, Y.S. and Du, P.F. (2017) Predicting Protein Submitochondrial Locations by Incorporating the Positional-Specific Physicochemical Properties into Chou's General Pseudo-Amino Acid Compositions. Journal of Theoretical Biology, 416, 81-87. https://doi.org/10.1016/j.jtbi.2016.12.026

50. Ju, Z. and He, J.J. (2017) Prediction of Lysine Crotonylation Sites by Incorporating the Composition of k-Spaced Amino Acid Pairs into Chou's General PseAAC. Journal of Molecular Graphics and Modelling, 77, 200-204. https://doi.org/10.1016/j.jmgm.2017.08.020

51. Khan, M., Hayat, M., Khan, S.A. and Iqbal, N. (2017) Unb-DPC: Identify Mycobacterial Membrane Protein Types by Incorporating Un-Biased Dipeptide Composition into Chou's General PseAAC. Journal of Theoretical Biology, 415, 13-19. https://doi.org/10.1016/j.jtbi.2016.12.004

52. Liang, Y. and Zhang, S. (2017) Predict Protein Structural Class by Incorporating Two Different Modes of Evolutionary Information into Chou's General Pseudo Amino Acid Composition. Journal of Molecular Graphics and Modelling, 78, 110-117. https://doi.org/10.1016/j.jmgm.2017.10.003

53. Meher, P.K., Sahu, T.K., Saini, V. and Rao, A.R. (2017) Predicting Antimicrobial Peptides with Improved Accuracy by Incorporating the Compositional, Physico-Chemical and Structural Features into Chou's General PseAAC. Scientific Reports, 7, Article No. 42362. https://doi.org/10.1038/srep42362

54. Qiu, W.R., Zheng, Q.S., Sun, B.Q. and Xiao, X. (2017) Multi-iPPseEvo: A Multi-Label Classifier for Identifying Human Phosphorylated Proteins by Incorporating Evolutionary Information into Chou's General PseAAC via Grey System Theory. Molecular Informatics, 36, Article ID: 1600085. https://doi.org/10.1002/minf.201600085

55. Xu, C., Ge, L., Zhang, Y., Dehmer, M. and Gutman, I. (2017) Prediction of Therapeutic Peptides by Incorporating q-Wiener Index into Chou's General PseAAC. Journal of Biomedical Informatics, 75, 63-69. 
56. Butt, A.H., Rasool, N. and Khan, Y.D. (2018) Predicting Membrane Proteins and Their Types by Extracting Various Sequence Features into Chou's General PseAAC. Molecular Biology Reports, 45, 2295-2306. https://doi.org/10.1007/s11033-018-4391-5

57. Ghauri, A.W., Khan, Y.D., Rasool, N., Khan, S.A. and Chou, K.C. (2018) pNitro-Tyr-PseAAC: Predict Nitrotyrosine Sites in Proteins by Incorporating Five Features into Chou's General PseAAC. Current Pharmaceutical Design, 24, 4034-4043. https://doi.org/10.2174/1381612825666181127101039

58. Ju, Z. and Wang, S.Y. (2018) Prediction of Citrullination Sites by Incorporating k-Spaced Amino Acid Pairs into Chou's General Pseudo Amino Acid Composition. Gene, 664, 78-83. https://doi.org/10.1016/j.gene.2018.04.055

59. Krishnan, M.S. (2018) Using Chou's General PseAAC to Analyze the Evolutionary Relationship of Receptor Associated Proteins (RAP) with Various Folding Patterns of Protein Domains. Journal of Theoretical Biology, 445, 62-74. https://doi.org/10.1016/j.jtbi.2018.02.008

60. Liang, Y. and Zhang, S. (2018) Identify Gram-Negative Bacterial Secreted Protein Types by Incorporating Different Modes of PSSM into Chou's General PseAAC via Kullback-Leibler Divergence. Journal of Theoretical Biology, 454, 22-29. https://doi.org/10.1016/j.jtbi.2018.05.035

61. Mei, J., Fu, Y. and Zhao, J. (2018) Analysis and Prediction of Ion Channel Inhibitors by Using Feature Selection and Chou's General Pseudo Amino Acid Composition. Journal of Theoretical Biology, 456, 41-48.

https://doi.org/10.1016/j.jtbi.2018.07.040

62. Mei, J. and Zhao, J. (2018) Analysis and Prediction of Presynaptic and Postsynaptic Neurotoxins by Chou's General Pseudo Amino Acid Composition and Motif Features. Journal of Theoretical Biology, 427, 147-153. https://doi.org/10.1016/j.jtbi.2018.03.034

63. Rahman, S.M., Shatabda, S., Saha, S., Kaykobad, M. and Sohel Rahman, M. (2018) DPP-PseAAC: A DNA-Binding Protein Prediction Model Using Chou's General PseAAC. Journal of Theoretical Biology, 452, 22-34. https://doi.org/10.1016/j.jtbi.2018.05.006

64. Sankari, E.S. and Manimegalai, D.D. (2018) Predicting Membrane Protein Types by Incorporating a Novel Feature Set into Chou's General PseAAC. Journal of Theoretical Biology, 455, 319-328.

https://doi.org/10.1016/j.jtbi.2018.07.032

65. Srivastava, A., Kumar, R. and Kumar, M. (2018) BlaPred: Predicting and Classifying Beta-Lactamase Using a 3-Tier Prediction System via Chou's General PseAAC. Journal of Theoretical Biology, 457, 29-36. https://doi.org/10.1016/j.jtbi.2018.08.030

66. Zhang, S. and Duan, X. (2018) Prediction of Protein Subcellular Localization with Oversampling Approach and Chou's General PseAAC. Journal of Theoretical Biology, 437, 239-250. https://doi.org/10.1016/j.jtbi.2017.10.030

67. Adilina, S., Farid, D.M. and Shatabda, S. (2019) Effective DNA Binding Protein Prediction by Using Key Features via Chou's General PseAAC. Journal of Theoretical Biology, 460, 64-78.

https://doi.org/10.1016/j.jtbi.2018.10.027

68. Behbahani, M., Nosrati, M., Moradi, M. and Mohabatkar, H. (2019) Using Chou's General Pseudo Amino Acid Composition to Classify Laccases from Bacterial and Fungal Sources via Chou's Five-Step Rule. Applied Biochemistry and Biotechnology, 190, 1035-1048. https://doi.org/10.1007/s12010-019-03141-8

69. Chen, G., Cao, M., Yu, J., Guo, X. and Shi, S. (2019) Prediction and Functional Analysis of Prokaryote Lysine Acetylation Site by Incorporating Six Types of Features into Chou's General PseAAC. Journal of Theoretical Biology, 461, 92-101. https://doi.org/10.1016/j.jtbi.2018.10.047

70. Nazari, I., Tahir, M., Tayari, H. and Chong, K.T. (2019) iN6-Methyl (5-Step): Identifying RNA N6-Methyladenosine Sites Using Deep Learning Mode via Chou's 5-Step Rules and Chou's General PseKNC. Chemometrics and Intelligent Laboratory Systems, 193, Article ID: 103811. https://doi.org/10.1016/j.chemolab.2019.103811 
71. Shen, Y., Tang, J. and Guo, F. (2019) Identification of Protein Subcellular Localization via Integrating Evolutionary and Physicochemical Information into Chou's General PseAAC. Journal of Theoretical Biology, 462, 230-239. https://doi.org/10.1016/j.jtbi.2018.11.012

72. Wang, L., Zhang, R. and Mu, Y. (2019) Fu-SulfPred: Identification of Protein S-Sulfenylation Sites by Fusing Forests via Chou's General PseAAC. Journal of Theoretical Biology, 461, 51-58. https://doi.org/10.1016/j.jtbi.2018.10.046

73. Xiao, X., Cheng, X., Chen, G., Mao, Q. and Chou, K.C. (2019) pLoc_bal-mVirus: Predict Subcellular Localization of Multi-Label Virus Proteins by Chou's General PseAAC and IHTS Treatment to Balance Training Dataset. Medicinal Chemistry, 15, 496-509. https://doi.org/10.2174/1573406415666181217114710

74. Behbahani, M., Nosrati, M., Moradi, M. and Mohabatkar, H. (2020) Using Chou's General Pseudo Amino Acid Composition to Classify Laccases from Bacterial and Fungal Sources via Chou's Five-Step Rule. Applied Biochemistry and Biotechnology, 190, 1035-1048. https://doi.org/10.1007/s12010-019-03141-8

75. Chen, Y. and Fan, X. (2019) Use Chou's 5-Steps Rule to Reveal Active Compound and Mechanism of Shuangsheng Pingfei San on Idiopathic Pulmonary Fibrosis. Current Molecular Medicine, 20, 220-230.

https://doi.org/10.2174/1566524019666191011160543

76. Du, X., Diao, Y., Liu, H. and Li, S. (2019) MsDBP: Exploring DNA-Binding Proteins by Integrating Multi-Scale Sequence Information via Chou's 5-Steps Rule. Journal of Proteome Research, 18, 3119-3132. https://doi.org/10.1021/acs.jproteome.9b00226

77. Dutta, A., Dalmia, A., A. R, Singh, K.K. and Anand, A. (2019) Using the Chou's 5-Steps Rule to Predict Splice Junctions with Interpretable Bidirectional Long Short-Term Memory Networks. Computers in Biology and Medicine, 116, Article ID: 103558. https://doi.org/10.1016/j.compbiomed.2019.103558

78. Hussain, W., Khan, S.D., Rasool, N., Khan, S.A. and Chou, K.C. (2019) SPalmitoylC-PseAAC: A Sequence-Based Model Developed via Chou's 5-Steps Rule and General PseAAC for Identifying S-Palmitoylation Sites in Proteins. Analytical Biochemistry, 568, 14-23. https://doi.org/10.1016/j.ab.2018.12.019

79. Hussain, W., Khan, Y.D., Rasool, N., Khan, S.A. and Chou, K.C. (2019) SPrenylC-PseAAC: A Sequence-Based Model Developed via Chou's 5-Steps Rule and General PseAAC for Identifying S-Prenylation Sites in Proteins. Journal of Theoretical Biology, 468, 1-11. https://doi.org/10.1016/j.jtbi.2019.02.007

80. Jun, Z. and Wang, S.Y. (2019) Identify Lysine Neddylation Sites Using Bi-Profile Bayes Feature Extraction via the Chou's 5-Steps Rule and General Pseudo Components. Current Genomics, 20, 592-601. https://doi.org/10.2174/1389202921666191223154629

81. Khan, S., Khan, M., Iqbal, N., Hussain, T., Khan, S.A. and Chou, K.C. (2020) A Two-Level Computation Model Based on Deep Learning Algorithm for Identification of piRNA and Their Functions via Chou's 5-Steps Rule. International Journal of Peptide Research and Therapeutics, 26, 795-809. https://doi.org/10.1007/s10989-019-09887-3

82. Lan, J., Liu, J., Liao, C., Merkler, D.J., Han, Q. and Li, J. (2019) A Study for Therapeutic Treatment against Parkinson's Disease via Chou's 5-Steps Rule. Current Topics in Medicinal Chemistry, 19, 2318-2333. http://www.eurekaselect.com/175887/article https://doi.org/10.2174/1568026619666191019111528

83. Liang, R., Xie, J., Zhang, C., Zhang, M., Huang, H., Huo, H., Cao, X. and Niu, B. (2019) Identifying Cancer Targets Based on Machine Learning Methods via Chou's 5-Steps Rule and General Pseudo Components. Current Topics in Medicinal Chemistry, 19, 2301-2317. https://doi.org/10.2174/1568026619666191016155543

84. Liang, Y. and Zhang, S. (2019) Identifying DNase I Hypersensitive Sites Using Multi-Features Fusion and F-Score Features Selection via Chou’s 5-Steps Rule. Biophysical Chemistry, 253, Article ID: 106227. https://doi.org/10.1016/j.bpc.2019.106227 
85. Wiktorowicz, A., Wit, A., Dziewierz, A., Rzeszutko, L., Dudek, D. and Kleczynski, P. (2019) Calcium Pattern Assessment in Patients with Severe Aortic Stenosis via the Chou's 5-Steps Rule. Current Pharmaceutical Design, 25, 3769-3775. https://doi.org/10.2174/1381612825666190930101258

86. Yang, L., Lv, Y., Wang, S., Zhang, Q., Pan, Y., Su, D., Lu, Q. and Zuo, Y. (2019) Identifying FL11 Subtype by Characterizing Tumor Immune Microenvironment in Prostate Adenocarcinoma via Chou's 5-Steps Rule. Genomics, 112, 1500-1515. https://doi.org/10.1016/j.ygeno.2019.08.021

87. Akmal, M.A., Hussain, W., Rasool, N., Khan, Y.D., Khan, S.A. and Chou, K.C. (2020) Using Chou's 5-Steps Rule to Predict O-Linked Serine Glycosylation Sites by Blending Position Relative Features and Statistical Moment. IEEE/ ACM Transactions on Computational Biology and Bioinformatics, in press.

https://doi.org/10.1109/TCBB.2020.2968441

88. Charoenkwan, P., Schaduangrat, N., Nantasenamat, C., Piacham, T. and Shoombuatong, W. (2020) iQSP: A Sequence-Based Tool for the Prediction and Analysis of Quorum Sensing Peptides via Chou's 5-Steps Rule and Informative Physicochemical Properties. International Journal of Molecular Sciences, 21, 75. https://doi.org/10.3390/ijms21010075

89. Charoenkwan, P., Schaduangrat, N., Nantasenamat, C., Piacham, T. and Shoombuatong, W. (2020) Correction: Shoombuatong, W., et al. iQSP: A Sequence-Based Tool for the Prediction and Analysis of Quorum Sensing Peptides via Chou's 5-Steps Rule and Informative Physicochemical Properties. Int. J. Mol. Sci. 2020, 21, 75. International Journal of Molecular Sciences, 21, 2629. https://doi.org/10.3390/ijms21072629

90. Chen, Y. and Fan, X. (2020) Use of Chou's 5-Steps Rule to Reveal Active Compound and Mechanism of Shuangshen Pingfei San on Idiopathic Pulmonary Fibrosis. Current Molecular Medicine, 20, 220-230. https://doi.org/10.2174/1566524019666191011160543

91. Du, L., Meng, Q., Jiang, H. and Li, Y. (2020) Using Evolutionary Information and Multi-Label Linear Discriminant Analysis to Predict the Subcellular Location of Multi-Site Bacterial Proteins via Chou's 5-Steps Rule. IEEE Access, 8, 56452-56461. https://doi.org/10.1109/ACCESS.2020.2982160

92. Dutta, A., Dalmia, A., A. R, Singh, K.K. and Anand, A. (2020) Using the Chou's 5-Steps Rule to Predict Splice Junctions with Interpretable Bidirectional Long Short-Term Memory Networks. Computers in Biology and Medicine, 116, Article ID: 103558. https://doi.org/10.1016/j.compbiomed.2019.103558

93. Ju, Z. and Wang, S.Y. (2020) Prediction of Lysine Formylation Sites Using the Composition of k-Spaced Amino Acid Pairs via Chou's 5-Steps Rule and General Pseudo Components. Genomics, 112, 859-866.

https://doi.org/10.1016/j.ygeno.2019.05.027

94. Kabir, M., Ahmad, S., Iqbal, M. and Hayat, M. (2020) iNR-2L: A Two-Level Sequence-Based Predictor Developed via Chou's 5-Steps Rule and General PseAAC for Identifying Nuclear Receptors and Their Families. Genomics, 112, 276-285. https://doi.org/10.1016/j.ygeno.2019.02.006

95. Lin, W., Xiao, X., Qiu, W. and Chou, K.C. (2020) Use Chou's 5-Steps Rule to Predict Remote Homology Proteins by Merging Grey Incidence Analysis and Domain Similarity Analysis. Natural Science, 12, 181-198.

https://doi.org/10.4236/ns.2020.123016

96. Vundavilli, H., Datta, A., Sima, C., Hua, J., Lopes, R. and Bittner, M. (2020) Using Chou's 5-Steps Rule to Model Feedback in Lung Cancer. IEEE Journal of Biomedical and Health Informatics. (In Press) https://doi.org/10.1109/JBHI.2019.2958042

97. Yang, L., Lv, Y., Wang, S., Zhang, Q., Pan, Y., Su, D., Lu, Q. and Zuo, Y. (2020) Identifying FL11 Subtype by Characterizing Tumor Immune Microenvironment in Prostate Adenocarcinoma via Chou's 5-Steps Rule. Genomics, 112, 1500-1515. https://doi.org/10.1016/j.ygeno.2019.08.021

98. Chou, K.C., Lin, W.Z. and Xiao, X. (2011) Wenxiang: A Web-Server for Drawing Wenxiang Diagrams. Natural Science, 3, 862-865. https://doi.org/10.4236/ns.2011.310111 
99. Zhou, G.P. (2011) The Disposition of the LZCC Protein Residues in Wenxiang Diagram Provides New Insights into the Protein-Protein Interaction Mechanism. Journal of Theoretical Biology, 284, 142-148. https://doi.org/10.1016/j.jtbi.2011.06.006

100. Zhou, G.P., Chen, D., Liao, S. and Huang, R.B. (2016) Recent Progresses in Studying Helix-Helix Interactions in Proteins by Incorporating the Wenxiang Diagram into the NMR Spectroscopy. Current Topics in Medicinal Chemistry, 16, 581-590. https://doi.org/10.2174/1568026615666150819104617

101. Chou, K.C. (1993) A Vectorized Sequence-Coupling Model for Predicting HIV Protease Cleavage Sites in Proteins. The Journal of Biological Chemistry, 268, 16938-16948.

102. Chou, K.C. and Zhang, C.T. (1992) Diagrammatization of Codon Usage in 339 HIV Proteins and Its Biological Implication. AIDS Research and Human Retroviruses, 8, 1967-1976. https://doi.org/10.1089/aid.1992.8.1967

103. Chou, J.J. (1993) Predicting Cleavability of Peptide Sequences by HIV Protease via Correlation-Angle Approach. Journal of Protein Chemistry, 12, 291-302. https://doi.org/10.1007/BF01028191

104. Chou, K.C., Tomasselli, A.L., Reardon, I.M. and Heinrikson, R.L. (1996) Predicting HIV Protease Cleavage Sites in Proteins by a Discriminant Function Method. Proteins. Structure, Function, and Bioinformatics, 24, 51-72. https://doi.org/10.1002/(SICI)1097-0134(199601)24:1<51::AID-PROT4>3.0.CO;2-R

105. Chou, K.C. and Zhang, C.T. (1993) Studies on the Specificity of HIV Protease: An Application of Markov Chain Theory. Journal of Protein Chemistry, 12, 709-724. https://doi.org/10.1007/BF01024929

106. Chou, K.C., Zhang, C.T. and Kezdy, F.J. (1993) A Vector Approach to Predicting HIV Protease Cleavage Sites in Proteins. Proteins: Structure, Function, and Bioinformatics, 16, 195-204. https://doi.org/10.1002/prot.340160206

107. Chou, K.C. and Forsen, S. (1980) Graphical Rules for Enzyme-Catalyzed Rate Laws. Biochemical Journal, 187, 829-835. https://doi.org/10.1042/bj1870829

108. Chou, K.C. (1981) A New Graphical Rule for Rate Laws of Enzyme Reactions with Branched Pathways. Canadian Journal of Biochemistry, 59, 757-761. https://doi.org/10.1139/o81-105

109. Chou, K.C., Carter, R.E. and Forsen, S. (1981) A New Graphical Method for Deriving Rate Equations for Complicated Mechanisms. Chemica Scripta, 18, 82-86.

110. Chou, K.C. and Forsen, S. (1981) Graphical Rules of Steady-State Reaction Systems. Canadian Journal of Chemistry, 59, 737-755. https://doi.org/10.1139/v81-107

111. Chou, K.C. and Liu, W.M. (1981) Graphical Rules for Non-Steady State Enzyme Kinetics. Journal of Theoretical Biology, 91, 637-654. https://doi.org/10.1016/0022-5193(81)90215-0

112. Chou, K.C. (1983) Advances in Graphical Methods of Enzyme Kinetics. Biophysical Chemistry, 17, 51-55. https://doi.org/10.1016/0301-4622(83)87013-6

113. Chou, K.C. (1989) Graphic Rules in Steady and Non-Steady Enzyme Kinetics. The Journal of Biological Chemistry, 264, 12074-12079.

114. Chou, K.C. (1993) Graphic Rule for Non-Steady-State Enzyme Kinetics and Protein Folding Kinetics. Journal of Mathematical Chemistry, 12, 97-108. https://doi.org/10.1007/BF01164628

115. Chou, K.C. (2010) Graphic Rule for Drug Metabolism Systems. Current Drug Metabolism, 11, 369-378. https://doi.org/10.2174/138920010791514261

116. Chou, K.C., Chen, N.Y. and Forsen, S. (1981) The Biological Functions of Low-Frequency Phonons: 2. Cooperative Effects. Chemica Scripta, 18, 126-132.

117. Chou, K.C., Li, T.T. and Forsen, S. (1980) The Critical Spherical Shell in Enzymatic Fast Reaction Systems. Biophysical Chemistry, 12, 265-269. https://doi.org/10.1016/0301-4622(80)80003-2

118. Chou, K.C. and Forsen, S. (1980) Diffusion-Controlled Effects in Reversible Enzymatic Fast Reaction System: 
Critical Spherical Shell and Proximity Rate Constants. Biophysical Chemistry, 12, 255-263.

https://doi.org/10.1016/0301-4622(80)80002-0

119. Li, T.T., Chou, K.C. and Forsen, S. (1980) The Flow of Substrate Molecules in Fast Enzyme-Catalyzed Reaction Systems. Chemica Scripta, 16, 192-196.

120. Chou, K.C., Forsen, S. and Zhou, G.Q. (1980) Three Schematic Rules for Deriving Apparent Rate Constants. Chemica Scripta, 16, 109-113.

121. Chou, K.C. (1983) Low-Frequency Vibrations of Helical Structures in Protein Molecules. Biochemical Journal, 209, 573-580. https://doi.org/10.1042/bj2090573

122. Chou, K.C. (1983) Identification of Low-Frequency Modes in Protein Molecules. Biochemical Journal, 215, 465-469. https://doi.org/10.1042/bj2150465

123. Zhou, G.P. and Deng, M.H. (1984) An Extension of Chou's Graphic Rules for Deriving Enzyme Kinetic Equations to Systems Involving Parallel Reaction Pathways. Biochemical Journal, 222, 169-176. https://doi.org/10.1042/bj2220169

124. Chou, K.C. (1984) Biological Functions of Low-Frequency Vibrations (Phonons). III. Helical Structures and Microenvironment. Biophysical Journal, 45, 881-889. https://doi.org/10.1016/S0006-3495(84)84234-4

125. Chou, K.C. (1984) The Biological Functions of Low-Frequency Phonons. 4. Resonance Effects and Allosteric Transition. Biophysical Chemistry, 20, 61-71. https://doi.org/10.1016/0301-4622(84)80005-8

126. Chou, K.C. (1984) Low-Frequency Vibrations of DNA Molecules. Biochemical Journal, 221, 27-31. https://doi.org/10.1042/bj2210027

127. Chou, K.C. (1985) Low-Frequency Motions in Protein Molecules: Beta-Sheet and Beta-Barrel. Biophysical Journal, 48, 289-297. https://doi.org/10.1016/S0006-3495(85)83782-6

128. Chou, K.C. (1985) Prediction of a Low-Frequency Mode in Bovine Pancreatic Trypsin Inhibitor Molecule. International Journal of Biological Macromolecules, 7, 77-80. https://doi.org/10.1016/0141-8130(85)90035-2

129. Chou, K.C. and Kiang, Y.S. (1985) The Biological Functions of Low-Frequency Phonons: 5. A Phenomenological Theory. Biophysical Chemistry, 22, 219-235. https://doi.org/10.1016/0301-4622(85)80045-4

130. Chou, K.C. (1986) Origin of Low-Frequency Motion in Biological Macromolecules: A View of Recent Progress of Quasi-Continuity Model. Biophysical Chemistry, 25, 105-116. https://doi.org/10.1016/0301-4622(86)87001-6

131. Chou, K.C. (1987) The Biological Functions of Low-Frequency Phonons: 6. A Possible Dynamic Mechanism of Allosteric Transition in Antibody Molecules. Biopolymers, 26, 285-295. https://doi.org/10.1002/bip.360260209

132. Chou, K.C. (1988) Review: Low-Frequency Collective Motion in Biomacromolecules and Its Biological Functions. Biophysical Chemistry, 30, 3-48. https://doi.org/10.1016/0301-4622(88)85002-6

133. Chou, K.C. and Maggiora, G.M. (1988) The Biological Functions of Low-Frequency Phonons: 7. The Impetus for DNA to Accommodate Intercalators. British Polymer Journal, 20, 143-148. https://doi.org/10.1002/pi.4980200209

134. Chou, K.C. (1989) Low-Frequency Resonance and Cooperativity of Hemoglobin. Trends in Biochemical Sciences, 14, 212-213. https://doi.org/10.1016/0968-0004(89)90026-1

135. Chou, K.C., Maggiora, G.M. and Mao, B. (1989) Quasi-Continuum Models of Twist-Like and Accordion-Like Low-Frequency Motions in DNA. Biophysical Journal, 56, 295-305. https://doi.org/10.1016/S0006-3495(89)82676-1

136. Chou, K.C. (1990) Review: Applications of Graph Theory to Enzyme Kinetics and Protein Folding Kinetics. Steady and Non-Steady State Systems. Biophysical Chemistry, 35, 1-24.

https://doi.org/10.1016/0301-4622(90)80056-D 
137. Althaus, I.W., Chou, J.J., Gonzales, A.J., Diebel, M.R., Chou, K.C., Kezdy, F.J., Romero, D.L., Aristoff, P.A., Tarpley, W.G. and Reusser, F. (1993) Steady-State Kinetic Studies with the Non-Nucleoside HIV-1 Reverse Transcriptase Inhibitor U-87201E. The Journal of Biological Chemistry, 268, 6119-6124.

138. Althaus, I.W., Gonzales, A.J., Chou, J.J., Diebel, M.R., Chou, K.C., Kezdy, F.J., Romero, D.L., Aristoff, P.A., Tarpley, W.G. and Reusser, F. (1993) The Quinoline U-78036 Is a Potent Inhibitor of HIV-1 Reverse Transcriptase. The Journal of Biological Chemistry, 268, 14875-14880.

139. Althaus, I.W., Chou, J.J., Gonzales, A.J., Diebel, M.R., Chou, K.C., Kezdy, F.J., Romero, D.L., Aristoff, P.A., Tarpley, W.G. and Reusser, F. (1993) Kinetic Studies with the Nonnucleoside HIV-1 Reverse Transcriptase Inhibitor U-88204E. Biochemistry, 32, 6548-6554. https://doi.org/10.1021/bi00077a008

140. Althaus, I.W., Chou, J.J., Gonzales, A.J., Diebel, M.R., Chou, K.C., Kezdy, F.J., Romero, D.L., Aristoff, P.A., Tarpley, W.G. and Reusser, F. (1994) Steady-State Kinetic Studies with the Polysulfonate U-9843, an HIV Reverse Transcriptase Inhibitor. Experientia, 50, 23-28. https://doi.org/10.1007/BF01992044

141. Althaus, I.W., Chou, J.J., Gonzales, A.J., Diebel, M.R., Chou, K.C., Kezdy, F.J., Romero, D.L., Thomas, R.C., Aristoff, P.A., Tarpley, W.G. and Reusser, F. (1994) Kinetic Studies with the Non-Nucleoside Human Immunodeficiency Virus Type-1 Reverse Transcriptase Inhibitor U-90152E. Biochemical Pharmacology, 47, 2017-2028. https://doi.org/10.1016/0006-2952(94)90077-9

142. Chou, K.C., Kezdy, F.J. and Reusser, F. (1994) Review: Kinetics of Processive Nucleic Acid Polymerases and Nucleases. Analytical Biochemistry, 221, 217-230. https://doi.org/10.1006/abio.1994.1405

143. Chou, K.C., Zhang, C.T. and Maggiora, G.M. (1994) Solitary Wave Dynamics as a Mechanism for Explaining the Internal Motion during Microtubule Growth. Biopolymers, 34, 143-153.

https://doi.org/10.1002/bip.360340114

144. Althaus, I.W., Chou, K.C., Franks, K.M., Diebel, M.R., Kezdy, F.J., Romero, D.L., Thomas, R.C., Aristoff, P.A., Tarpley, W.G. and Reusser, F. (1996) The Benzylthio-Pyrididine U-31,355, a Potent Inhibitor of HIV-1 Reverse Transcriptase. Biochemical Pharmacology, 51, 743-750. https://doi.org/10.1016/0006-2952(95)02390-9

145. Liu, H., Wang, M. and Chou, K.C. (2005) Low-Frequency Fourier Spectrum for Predicting Membrane Protein Types. Biochemical and Biophysical Research Communications (BBRC), 336, 737-739.

https://doi.org/10.1016/j.bbrc.2005.08.160

146. Gordon, G. (2007) Designed Electromagnetic Pulsed Therapy: Clinical Applications. Journal of Cellular Physiology, 212, 579-582. https://doi.org/10.1002/jcp.21025

147. Andraos, J. (2008) Kinetic Plasticity and the Determination of Product Ratios for Kinetic Schemes Leading to Multiple Products without Rate Laws: New Methods Based on Directed Graphs. Canadian Journal of Chemistry, 86, 342-357. https://doi.org/10.1139/v08-020

148. Chou, K.C. and Shen, H.B. (2009) FoldRate: A Web-Server for Predicting Protein Folding Rates from Primary Sequence. The Open Bioinformatics Journal, 3, 31-50. https://doi.org/10.2174/1875036200903010031

149. Shen, H.B., Song, J.N. and Chou, K.C. (2009) Prediction of Protein Folding Rates from Primary Sequence by Fusing Multiple Sequential Features. Journal of Biomedical Science and Engineering (JBiSE), 2, 136-143. https://doi.org/10.4236/jbise.2009.23024

150. Wang, J.F. and Chou, K.C. (2009) Insight into the Molecular Switch Mechanism of Human Rab5a from Molecular Dynamics Simulations. Biochemical and Biophysical Research Communications (BBRC), 390, 608-612. https://doi.org/10.1016/j.bbrc.2009.10.014

151. Gordon, G. (2008) Extrinsic Electromagnetic Fields, Low Frequency (Phonon) Vibrations, and Control of Cell Function: A Non-Linear Resonance System. Journal of Biomedical Science and Engineering (JBiSE), 1, 152-156. https://doi.org/10.4236/jbise.2008.13025 
152. Madkan, A., Blank, M., Elson, E., Chou, K.C., Geddis, M.S. and Goodman, R. (2009) Steps to the Clinic with ELF EMF. Natural Science, 1, 157-165. https://doi.org/10.4236/ns.2009.13020

153. Lian, P., Wei, D.Q., Wang, J.F. and Chou, K.C. (2011) An Allosteric Mechanism Inferred from Molecular Dynamics Simulations on Phospholamban Pentamer in Lipid Membranes. PLoS ONE, 6, e18587. https://doi.org/10.1371/journal.pone.0018587

154. Liao, Q.H., Gao, Q.Z., Wei, J. and Chou, K.C. (2011) Docking and Molecular Dynamics Study on the Inhibitory Activity of Novel Inhibitors on Epidermal Growth Factor Receptor (EGFR). Medicinal Chemistry, 7, 24-31. https://doi.org/10.2174/157340611794072698

155. Li, J., Wei, D.Q., Wang, J.F., Yu, Z.T. and Chou, K.C. (2012) Molecular Dynamics Simulations of CYP2E1. Medicinal Chemistry, 8, 208-221. https://doi.org/10.2174/157340612800493692

156. Wang, J.F. and Chou, K.C. (2012) Recent Advances in Computational Studies on Influenza a Virus M2 Proton Channel. Mini Reviews in Medicinal Chemistry, 12, 971-978. https://doi.org/10.2174/138955712802762275

157. Zhang, T., Wei, D.Q. and Chou, K.C. (2012) A Pharmacophore Model Specific to Active Site of CYP1A2 with a Novel Molecular Modeling Explorer and CoMFA. Medicinal Chemistry, 8, 198-207. https://doi.org/10.2174/157340612800493601

158. Jia, J., Liu, Z., Xiao, X. and Chou, K.C. (2015) iPPI-Esml: An Ensemble Classifier for Identifying the Interactions of Proteins by Incorporating Their Physicochemical Properties and Wavelet Transforms into PseAAC. Journal of Theoretical Biology, 377, 47-56. https://doi.org/10.1016/j.jtbi.2015.04.011

159. Jia, J., Liu, Z., Xiao, X., Liu, B. and Chou, K.C. (2016) Identification of Protein-Protein Binding Sites by Incorporating the Physicochemical Properties and Stationary Wavelet Transforms into Pseudo Amino Acid Compo sition (iPPBS-PseAAC). Journal of Biomolecular Structure and Dynamics (JBSD), 34, 1946-1961. https://doi.org/10.1080/07391102.2015.1095116

160. Chou, K.C. (2019) Proposing Pseudo Amino Acid Components Is an Important Milestone for Proteome and Genome Analyses. International Journal for Peptide Research and Therapeutics (IJPRT), 26, 1085-1098. https://doi.org/10.1007/s10989-019-09910-7

161. Chou, K.C. (2019) Artificial Intelligence (AI) Tools Constructed via the 5-Steps Rule for Predicting Post-Translational Modifications. Trends in Artificial Intelligence (TIA), 3, 60-74.

https://doi.org/10.36959/643/304

162. Chou, K.C. (2019) Impacts of Pseudo Amino Acid Components and 5-Steps Rule to Proteomics and Proteome Analysis. Current Topics in Medicinal Chemistry, 19, 2283-2300. https://doi.org/10.2174/1568026619666191018100141

163. Chou, K.C. (2019) Advance in Predicting Subcellular Localization of Multi-Label Proteins and Its Implication for Developing Multi-Target Drugs. Current Medicinal Chemistry, 26, 4918-4943. https://doi.org/10.2174/0929867326666190507082559

164. Shao, Y.T. and Chou, K.C. (2020) pLoc_Deep-mAnimal: A Novel Deep CNN-BLSTM Network to Predict Subcellular Localization of Animal Proteins. Natural Science, 12, 281-291. https://doi.org/10.4236/ns.2020.125024

165. Shao, Y.T. and Chou, K.C. (2020) pLoc_Deep-mEuk: Predict Subcellular Localization of Eukaryotic Proteins by Deep Learning. Natural Science, 12, 400-428. https://doi.org/10.4236/ns.2020.126034

166. Liu, X.X. and Chou, K.C. (2020) pLoc_Deep-mGneg: Predict Subcellular Localization of Gram Negative Bacterial Proteins by Deep Learning. Advances in Bioscience and Biotechnology $(A B B), 11,141-152$. https://doi.org/10.4236/abb.2020.115011

167. Shao, Y.T., Liu, X.X., Lu, Z. and Chou, K.C. (2020) pLoc_Deep-mHum: Predict Subcellular Localization of Human Proteins by Deep Learning. Natural Science, in press, 1-31. 
168. Shao, Y.T., Liu, X.X., Lu, Z. and Chou, K.C. (2020) pLoc_Deep-mPlant: Predict Subcellular Localization of Plant Proteins by Deep Learning. Natural Science, 12, 237-247. https://doi.org/10.4236/ns.2020.125021

169. Shao, Y.H. and Chou, K.C. (2020) pLoc_Deep-mVirus: A CNN Model for Predicting Subcellular Localization of Virus Proteins by Deep Learning. Natural Science, 12, 388-399. https://doi.org/10.4236/ns.2020.126033

170. Chou, K.C. (2020) Showcase to Illustrate How the Web-Server iATC_Deep-mISF Is Working. Global Journal of Science Frontier Research: G Bio-Tech \& Genetics, 20, 1-3.

171. K.-C. Chou (2020), Showcase to Illustrate How the Web-Server iKcr-PseEns Is Working. Journal of Medical Care Research and Review, 3, 331-347.

172. Chou, K.C. (2020) Showcase to Illustrate How the Web-Server iPTM-mLys Is Working. Infotext Journal of Infectious Diseases and Therapy (IJID), 1, 1-16.

173. Chou, K.C. (2020) Showcase to Illustrate How the Web-Server iRNA-Methyl Is Working. Journal of Molecular Genetics, 3, 1-7.

174. Chou, K.C. (2020) Showcase to Illustrate How the Web-Server iSNO-AAPair Is Working. Journal of Genetics and Genomics, 24, 18156-18160.

175. Chou, K.C. (2020) Showcase to Illustrate How the Web-Server pLoc_Deep-mAnimal Is Working. American Journal of Virology \& Disease, 2, 1-2.

176. Chou, K.C. (2020) Showcase to Illustrate How the Web-Server pLoc_Deep-mGneg Is Working. Clinical and Medical Case Report Journal, 1, 1-2.

177. Chou, K.C. (2020) Showcase to Illustrate How the Web-Server pLoc_Deep-mPlant Is Working. Integrative Molecular Biology and Biotechnology, 1, 1-2.

178. Chou, K.C. (2020) Showcase to Illustrate How the Web-Server pLoc_Deep-mVirus Is Working. Clinical Research and Trials, 6, 1-2.

179. K.-C. Chou (2020) Showcase to Illustrate How the Web-Server pSuc-Lys Is Working. Social Sciences and Humanities Open Access Journal, 1, 1-3.

180. Chou, K.C. (2020) Showcase to Illustrate How the Webserver pLoc_bal-mEuk Is Working. Biomedical Journal of Scientific \& Technical Research, 24, Article ID: 18156. https://doi.org/10.26717/BJSTR.2020.24.004033

181. Chou, K.C., Pottle, M., Nemethy, G., Ueda, Y. and Scheraga, H.A. (1982) Structure of Beta-Sheets: Origin of the Right-Handed Twist and of the Increased Stability of Antiparallel over Parallel Sheets. Journal of Molecular Biology, 162, 89-112. https://doi.org/10.1016/0022-2836(82)90163-2

182. Chou, K.C. and Scheraga, H.A. (1982) Origin of the Right-Handed Twist of Beta-Sheets of Poly(LVal) Chains. Proceedings of the National Academy of Sciences of the United States of America, 79, 7047-7051. https://doi.org/10.1073/pnas.79.22.7047

183. Chou, K.C., Nemethy, G. and Scheraga, H.A. (1983) Energetic Approach to Packing of $\alpha$-Helices: 1 . Equivalent Helices. The Journal of Physical Chemistry, 87, 2869-2881. https://doi.org/10.1021/j100238a033

184. Chou, K.C., Nemethy, G. and Scheraga, H.A. (1983) Role of Interchain Interactions in the Stabilization of Right-Handed Twist of $\beta$-Sheets. Journal of Molecular Biology, 168, 389-407.

https://doi.org/10.1016/S0022-2836(83)80025-4

185. Chou, K.C., Nemethy, G. and Scheraga, H.A. (1983) Effects of Amino Acid Composition on the Twist and the Relative Stability of Parallel and Antiparallel $\beta$-Sheets. Biochemistry, 22, 6213-6221.

https://doi.org/10.1021/bi00295a027

186. Chou, K.C., Nemethy, G. and Scheraga, H.A. (1984) Energetic Approach to Packing of $\alpha$-Helices: 2. General Treatment of Nonequivalent and Nonregular Helices. Journal of American Chemical Society, 106, 3161-3170. https://doi.org/10.1021/ja00323a017 
187. Scheraga, H.A., Chou, K.C. and Nemethy, G. (1984) Protein Structure and Function, from Colloidal to a Molecular View. Carlsberg Research Communications, 49, 1-55. https://doi.org/10.1007/BF02913964

188. Chou, K.C., Nemethy, G., Pottle, M.S. and Scheraga, H.A. (1985) The Folding of the Twisted Beta-Sheet in Bovine Pancreatic Trypsin Inhibitor. Biochemistry, 24, 7948-7953. https://doi.org/10.1021/bi00348a016

189. Chou, K.C., Nemethy, G., Rumsey, S., Tuttle, R.W. and Scheraga, H.A. (1985) Interactions between an $\alpha$-Helix and a $\beta$-Sheet: Energetics of $\alpha / \beta$ Packing in Proteins. Journal of Molecular Biology, 186, 591-609. https://doi.org/10.1016/0022-2836(85)90133-0

190. Gerritsen, M., Chou, K.C., Nemethy, G. and Scheraga, H.A. (1985) Energetics of Multi-Helix Interactions in Protein Folding: Application to Myoglobin. Biopolymers, 24, 1271-1291. https://doi.org/10.1002/bip.360240714

191. Chou, K.C., Nemethy, G., Rumsey, S., Tuttle, R.W. and Scheraga, H.A. (1986) Interactions between Two Beta-Sheets: Energetics of Beta/Beta Packing in Proteins. Journal of Molecular Biology, 188, 641-649. https://doi.org/10.1016/S0022-2836(86)80012-2

192. Chou, K.C., Maggiora, G.M., Nemethy, G. and Scheraga, H.A. (1988) Energetics of the Structure of the Four-Alpha-Helix Bundle in Proteins. Proceedings of the National Academy of Sciences of the United States of America, 85, 4295-4299. https://doi.org/10.1073/pnas.85.12.4295

193. Chou, K.C., Nemethy, G., Pottle, M. and Scheraga, H.A. (1989) Energy of Stabilization of the Right-Handed Beta-Alpha-Beta Crossover in Proteins. Journal of Molecular Biology, 205, 241-249. https://doi.org/10.1016/0022-2836(89)90378-1

194. Chou, K.C., Heckel, A., Nemethy, G., Rumsey, S., Carlacci, L. and Scheraga, H.A. (1990) Energetics of the Structure and Chain Tilting of Antiparallel Beta-Barrels In Proteins. Proteins. Structure, Function and Bioinformatics, 8, 14-22. https://doi.org/10.1002/prot.340080105

195. Chou, K.C., Nemethy, G. and Scheraga, H.A. (1990) Review: Energetics of Interactions of Regular Structural Elements in Proteins. Accounts of Chemical Research, 23, 134-141. https://doi.org/10.1021/ar00173a003

196. Chou, K.C., Maggiora, G.M. and Scheraga, H.A. (1992) The Role of Loop-Helix Interactions in Stabilizing Four-Helix Bundle Proteins. Proceedings of the National Academy of Sciences of the United States of America, 89, 7315-7319. https://doi.org/10.1073/pnas.89.16.7315

197. Chou, K.C. and Zhang, C.T. (1992) A Correlation Coefficient Method to Predicting Protein Structural Classes from Amino Acid Compositions. European Journal of Biochemistry, 207, 429-433. https://doi.org/10.1111/j.1432-1033.1992.tb17067.x

198. Zhang, C.T. and Chou, K.C. (1992) An Optimization Approach to Predicting Protein Structural Class from Amino Acid Composition. Protein Science, 1, 401-408. https://doi.org/10.1002/pro.5560010312

199. Chou, J.J. and Zhang, C.T. (1993) A Joint Prediction of the Folding Types of 1490 Human Proteins from Their Genetic Codons. Journal of Theoretical Biology, 161, 251-262. https://doi.org/10.1006/jtbi.1993.1053

200. Chou, K.C. and Zhang, C.T. (1993) A New Approach to Predicting Protein Folding Types. Journal of Protein Chemistry, 12, 169-178. https://doi.org/10.1007/BF01026038

201. Chou, K.C. and Zhang, C.T. (1994) Predicting Protein Folding Types by Distance Functions That Make Allowances for Amino Acid Interactions. Journal of Biological Chemistry, 269, 22014-22020.

202. Chou, K.C. and Zhang, C.T. (1995) Review: Prediction of Protein Structural Classes. Critical Reviews in Biochemistry and Molecular Biology, 30, 275-349. https://doi.org/10.3109/10409239509083488

203. Chou, K.C., Zhang, C.T., Kezdy, F.J. and Poorman, R.A. (1995) A Vector Projection Method for Predicting the Specificity of GalNAc-Transferase. Proteins. Structure, Function and Bioinformatics, 21, 118-126. https://doi.org/10.1002/prot.340210205

204. Zhang, C.T., Chou, K.C. and Maggiora, G.M. (1995) Predicting Protein Structural Classes from Amino Acid 
Composition: Application of Fuzzy Clustering. Protein Engineering, 8, 425-435.

https://doi.org/10.1093/protein/8.5.425

205. Chou, K.C., Zhang, C.T. and Elrod, D.W. (1996) Do Antisense Proteins Exist? Journal of Protein Chemistry, 15, 59-61. https://doi.org/10.1007/BF01886811

206. Maggiora, G.M., Zhang, C.T., Chou, K.C. and Elrod, D.W. (1996) Combining Fuzzy Clustering and Neural Networks to Predict Protein Structural Classes. In: Devillers, J., Ed., Neural Networks in QSAR and Drug Design, Academic Press, London, 255-279. https://doi.org/10.1016/B978-012213815-7/50012-1

207. Chou, K.C., Liu, W., Maggiora, G.M. and Zhang, C.T. (1998) Prediction and Classification of Domain Structural Classes. Proteins. Structure, Function and Bioinformatics, 31, 97-103. https://doi.org/10.1002/(SICI)1097-0134(19980401)31:1<97::AID-PROT8>3.0.CO;2-E

208. Chou, K.C. and Chen, N.Y. (1977) The Biological Functions of Low-Frequency Phonons. Scientia Sinica, 20, 447-457.

209. Chou, K.C., Jiang, S.P., Liu, W.M. and Fee, C.H. (1979) Graph Theory of Enzyme Kinetics: 1. Steady-State Reaction System. Scientia Sinica, 22, 341-358.

210. Huang, T., Chen, L., Cai, Y.D. and Chou, K.C. (2011) Classification and Analysis of Regulatory Pathways Using Graph Property, Biochemical and Physicochemical Property, and Functional Property. PLoS ONE, 6, e25297. https://doi.org/10.1371/journal.pone.0025297

211. Chou, K.C. and Jiang, S.P. (1974) Studies on the Rate of Diffusion-Controlled Reactions of Enzymes. Scientia Sinica, 17, 664-680.

212. Chou, K.C. (1975) Studies on the Enzyme Kinetics of the Cavity-Active Site. Acta Biochimica et Biophysica Sinica, 7, 95-103.

213. Chou, K.C., Kuo, C.K. and Li, T.T. (1975) The Quantitative Relations between Diffusion-Controlled Reaction Rate and Characteristic Parameters in Enzyme-Substrate Reaction System: 2. Charged Substrates. Scientia Sinica, 18, 366-380.

214. Chou, K.C. (1976) The Kinetics of the Combination Reaction between Enzyme and Substrate. Scientia Sinica, 19, 505-528.

215. Li, T.T. and Chou, K.C. (1976) The Quantitative Relations between Diffusion-Controlled Reaction Rate and Characteristic Parameters in Enzyme-Substrate Reaction System: 1. Neutral Substrates. Scientia Sinica, 19, 117-136.

216. Chou, K.C. (1977) The Kinetics of the Combination Reaction between Enzyme and Substrate: 1. Stochastic Analysis, Activation Energy and Multiple-Active-Site. Acta Biochimica et Biophysica Sinica, 9, 79-94.

217. Chou, K.C. (1977) The Kinetics of the Combination Reaction between Enzyme and Substrate: 2. Multi-Barrier Reaction and Measuring Signal. Acta Biochimica et Biophysica Sinica, 9, 175-186.

218. Chou, K.C. (1980) A New Schematic Method in Enzyme Kinetics. European Journal of Biochemistry, 113, 195-198. https://doi.org/10.1111/j.1432-1033.1980.tb06155.x

219. Chou, K.C. (1981) Two New Schematic Rules for Rate Laws of Enzyme-Catalyzed Reactions. Journal of Theoretical Biology, 89, 581-592. https://doi.org/10.1016/0022-5193(81)90030-8

220. Chou, K.C., Li, T.T. and Zhou, G.Q. (1981) A Semi-Analytical Expression for the Concentration Distribution of Substrate Molecules in Fast, Enzyme-Catalyzed Reaction Systems. Biochimica et Biophysica Acta $(B B A)$-Enzymology, 657, 304-308. https://doi.org/10.1016/0005-2744(81)90153-4

221. Chou, K.C. and Zhou, G.P. (1982) Role of the Protein Outside Active Site on the Diffusion-Controlled Reaction of Enzyme. Journal of American Chemical Society, 104, 1409-1413. https://doi.org/10.1021/ja00369a043

222. Chou, K.C. and Elrod, D.W. (2003) Prediction of Enzyme Family Classes. Journal of Proteome Research, 2, 
183-190. https://doi.org/10.1021/pr0255710

223. Chou, K.C. and Cai, Y.D. (2004) A Novel Approach to Predict Active Sites of Enzyme Molecules. Proteins: Structure, Function and Genetics, 55, 77-82. https://doi.org/10.1002/prot.10622

224. Chou, K.C. and Cai, Y.D. (2004) Predicting Enzyme Family Class in a Hybridization Space. Protein Science, 13, 2857-2863. https://doi.org/10.1110/ps.04981104

225. Chou, K.C. and Cai, Y.D. (2004) Using GO-PseAA Predictor to Predict Enzyme Sub-Class. Biochemical and Biophysical Research Communications (BBRC), 325, 506-509. https://doi.org/10.1016/j.bbrc.2004.10.058

226. Cai, Y.D. and Chou, K.C. (2005) Using Functional Domain Composition to Predict Enzyme Family Classes. Journal of Proteome Research, 4, 109-111. https://doi.org/10.1021/pr049835p

227. Cai, Y.D. and Chou, K.C. (2005) Predicting Enzyme Subclass by Functional Domain Composition and Pseudo Amino Acid Composition. Journal of Proteome Research, 4, 967-971. https://doi.org/10.1021/pr0500399

228. Cai, Y.D., Zhou, G.P. and Chou, K.C. (2005) Predicting Enzyme Family Classes by Hybridizing Gene Product Composition and Pseudo Amino Acid Composition. Journal of Theoretical Biology, 234, 145-149. https://doi.org/10.1016/j.jtbi.2004.11.017

229. Chou, K.C. (2005) Using Amphiphilic Pseudo Amino Acid Composition to Predict Enzyme Subfamily Classes. Bioinformatics, 21, 10-19. https://doi.org/10.1093/bioinformatics/bth466

230. Shen, H.B. and Chou, K.C. (2007) EzyPred: A Top-Down Approach for Predicting Enzyme Functional Classes and Subclasses. Biochemical and Biophysical Research Communications (BBRC), 364, 53-59. https://doi.org/10.1016/j.bbrc.2007.09.098

231. Wei, H., Zhang, R., Wang, C., Zheng, H., Chou, K.C. and Wei, D.Q. (2007) Molecular Insights of SAH Enzyme Catalysis and Their Implication for Inhibitor Design. Journal of Theoretical Biology, 244, 692-702. https://doi.org/10.1016/j.jtbi.2006.09.011

232. Min, J.L., Xiao, X. and Chou, K.C. (2013) iEzy-Drug: A Web Server for Identifying the Interaction between Enzymes and Drugs in Cellular Networking. BioMed Research International (BMRI), 2013, Article ID: 701317. https://doi.org/10.1155/2013/701317

233. Shen, H.B. and Chou, K.C. (2008) HIVcleave: A Web-Server for Predicting HIV Protease Cleavage Sites in Proteins. Analytical Biochemistry, 375, 388-390. https://doi.org/10.1016/j.ab.2008.01.012

234. Sirois, S., Touaibia, M., Chou, K.C. and Roy, R. (2007) Glycosylation of HIV-1 gp120 V3 Loop: Towards the Rational Design of a Synthetic Carbohydrate Vaccine. Current Medicinal Chemistry, 14, 3232-3242. https://doi.org/10.2174/092986707782793826

235. Gao, W.N., Wei, D.Q., Li, Y., Gao, H., Xu, W.R., Li, A.X. and Chou, K.C. (2007) Agaritine and Its Derivatives Are Potential Inhibitors against HIV Proteases. Medicinal Chemistry, 3, 221-226. https://doi.org/10.2174/157340607780620644

236. Sirois, S., Tsoukas, C.M., Chou, K.C., Wei, D.Q., Boucher, C. and Hatzakis, G.E. (2005) Selection of Molecular Descriptors with Artificial Intelligence for the Understanding of HIV-1 Protease Peptidomimetic Inhibitors-Activity. Medicinal Chemistry, 1, 173-184. https://doi.org/10.2174/1573406053175238

237. Sirois, S., Sing, T. and Chou, K.C. (2005) Review: HIV-1 gp120 V3 Loop for Structure-Based Drug Design. Current Protein and Peptide Science, 6, 413-422. https://doi.org/10.2174/138920305774329359

238. Cai, Y.D., Yu, H. and Chou, K.C. (1998) Using Neural Network for Prediction of HIV Protease Cleavage Sites in Proteins. Journal of Protein Chemistry, 17, 607-615. https://doi.org/10.1007/BF02780962

239. Xu, Y., Ding, J., Wu, L.Y. and Chou, K.C. (2013) iSNO-PseAAC: Predict Cysteine S-Nitrosylation Sites in Proteins by Incorporating Position Specific Amino Acid Propensity into Pseudo Amino Acid Composition. PLoS ONE, 8, e55844. https://doi.org/10.1371/journal.pone.0055844 
240. Xu, Y., Shao, X.J., Wu, L.Y., Deng, N.Y. and Chou, K.C. (2013) iSNO-AAPair: Incorporating Amino Acid Pairwise Coupling into PseAAC for Predicting Cysteine S-Nitrosylation Sites in Proteins. Peer), 1, e171. https://doi.org/10.7717/peerj.171

241. Xu, Y., Wen, X., Shao, X.J., Deng, N.Y. and Chou, K.C. (2014) iHyd-PseAAC: Predicting Hydroxyproline and Hydroxylysine in Proteins by Incorporating Dipeptide Position-Specific Propensity into Pseudo Amino Acid Composition. International Journal of Molecular Sciences, 15, 7594-7610. https://doi.org/10.3390/ijms15057594

242. Xu, Y., Wen, X., Wen, L.S., Wu, L.Y., Deng, N.Y. and Chou, K.C. (2014) iNitro-Tyr: Prediction of Nitrotyrosine Sites in Proteins with General Pseudo Amino Acid Composition. PLoS ONE, 9, e105018. https://doi.org/10.1371/journal.pone.0105018

243. Xu, Y. and Chou, K.C. (2016) Recent Progress in Predicting Posttranslational Modification Sites in Proteins. Current Topics in Medicinal Chemistry, 16, 591-603. https://doi.org/10.2174/1568026615666150819110421

244. Liu, L.M., Xu, Y. and Chou, K.C. (2017) iPGK-PseAAC: Identify Lysine Phosphoglycerylation Sites in Proteins by Incorporating Four Different Tiers of Amino Acid Pairwise Coupling Information into the General PseAAC. Medicinal Chemistry, 13, 552-559. https://doi.org/10.2174/1573406413666170515120507

245. Xu, Y., Li, C. and Chou, K.C. (2017) iPreny-PseAAC: Identify C-Terminal Cysteine Prenylation Sites in Proteins by Incorporating Two Tiers of Sequence Couplings into PseAAC. Medicinal Chemistry, 13, 544-551. https://doi.org/10.2174/1573406413666170419150052

246. Chen, W., Lin, H., Feng, P.M., Ding, C., Zuo, Y.C. and Chou, K.C. (2012) iNuc-PhysChem: A Sequence-Based Predictor for Identifying Nucleosomes via Physicochemical Properties. PLoS ONE, 7, e47843. https://doi.org/10.1371/journal.pone.0047843

247. Chen, W., Feng, P.M., Lin, H. and Chou, K.C. (2013) iRSpot-PseDNC: Identify Recombination Spots with Pseudo Dinucleotide Composition. Nucleic Acids Research, 41, e68. https://doi.org/10.1093/nar/gks1450

248. Feng, P.M., Chen, W., Lin, H. and Chou, K.C. (2013) iHSP-PseRAAAC: Identifying the Heat Shock Protein Families Using Pseudo Reduced Amino Acid Alphabet Composition. Analytical Biochemistry, 442, 118-125. https://doi.org/10.1016/j.ab.2013.05.024

249. Chen, W., Feng, P.M., Deng, E.Z., Lin, H. and Chou, K.C. (2014) iTIS-PseTNC: A Sequence-Based Predictor for Identifying Translation Initiation Site in Human Genes Using Pseudo Trinucleotide Composition. Analytical Biochemistry, 462, 76-83. https://doi.org/10.1016/j.ab.2014.06.022

250. Chen, W., Feng, P.M., Lin, H. and Chou, K.C. (2014) iSS-PseDNC: Identifying Splicing Sites Using Pseudo Dinucleotide Composition. Biomed Research International (BMRI), 2014, Article ID: 623149. https://doi.org/10.1155/2014/623149

251. Chen, W., Lei, T.Y., Jin, D.C., Lin, H. and Chou, K.C. (2014) PseKNC: A Flexible Web-Server for Generating Pseudo K-Tuple Nucleotide Composition. Analytical Biochemistry, 456, 53-60. https://doi.org/10.1016/j.ab.2014.04.001

252. Ding, H., Deng, E.Z., Yuan, L.F., Liu, L., Lin, H., Chen, W. and Chou, K.C. (2014) iCTX-Type: A Sequence-Based Predictor for Identifying the Types of Conotoxins in Targeting ion Channels. BioMed Research International (BMRI), 2014, Article ID: 286419. https://doi.org/10.1155/2014/286419

253. Guo, S.H., Deng, E.Z., Xu, L.Q., Ding, H., Lin, H., Chen, W. and Chou, K.C. (2014) iNuc-PseKNC: A Sequence-Based Predictor for Predicting Nucleosome Positioning in Genomes with Pseudo k-Tuple Nucleotide Composition. Bioinformatics, 30, 1522-1529. https://doi.org/10.1093/bioinformatics/btu083

254. Lin, H., Deng, E.Z., Ding, H., Chen, W. and Chou, K.C. (2014) iPro54-PseKNC: A Sequence-Based Predictor for Identifying Sigma-54 Promoters in Prokaryote with Pseudo k-Tuple Nucleotide Composition. Nucleic Acids Research, 42, 12961-12972. https://doi.org/10.1093/nar/gku1019 
255. Chen, W., Feng, P., Ding, H., Lin, H. and Chou, K.C. (2015) iRNA-Methyl: Identifying $\mathrm{N}^{6}$-Methyladenosine Sites Using Pseudo Nucleotide Composition. Analytical Biochemistry, 490, 26-33. https://doi.org/10.1016/j.ab.2015.08.021

256. Chen, W., Feng, P., Ding, H., Lin, H. and Chou, K.C. (2015) Benchmark Data for Identifying $\mathrm{N}^{6}$-Methyladenosine Sites in the Saccharomyces cerevisiae Genome. Data in Brief, 5, 376-378. https://doi.org/10.1016/j.dib.2015.09.008

257. Chen, W., Lin, H. and Chou, K.C. (2015) Pseudo Nucleotide Composition or PseKNC: An Effective Formulation for Analyzing Genomic Sequences. Molecular BioSystems, 11, 2620-2634. https://doi.org/10.1039/C5MB00155B

258. Chen, W., Zhang, X., Brooker, J., Lin, H., Zhang, L. and Chou, K.C. (2015) PseKNC-General: A Cross-Platform Package for Generating Various Modes of Pseudo Nucleotide Compositions. Bioinformatics, 31, 119-120. https://doi.org/10.1093/bioinformatics/btu602

259. Chen, W., Ding, H., Feng, P., Lin, H. and Chou, K.C. (2016) iACP: A Sequence-Based Tool for Identifying Anticancer Peptides. Oncotarget, 7, 16895-16909. https://doi.org/10.18632/oncotarget.7815

260. Chen, W., Feng, P., Ding, H., Lin, H. and Chou, K.C. (2016) Using Deformation Energy to Analyze Nucleosome Positioning in Genomes. Genomics, 107, 69-75. https://doi.org/10.1016/j.ygeno.2015.12.005

261. Chen, W., Tang, H., Ye, J., Lin, H. and Chou, K.C. (2016) iRNA-PseU: Identifying RNA Pseudouridine Sites. Molecular Therapy-Nucleic Acids, 5, e332.

262. Zhang, C.J., Tang, H., Li, W.C., Lin, H., Chen, W. and Chou, K.C. (2016) iOri-Human: Identify Human Origin of Replication by Incorporating Dinucleotide Physicochemical Properties into Pseudo Nucleotide Composition. Oncotarget, 7, 69783-69793. https://doi.org/10.18632/oncotarget.11975

263. Chen, W., Feng, P., Yang, H., Ding, H., Lin, H. and Chou, K.C. (2017) iRNA-AI: Identifying the Adenosine to Inosine Editing Sites in RNA Sequences. Oncotarget, 8, 4208-4217. https://doi.org/10.18632/oncotarget.13758

264. Feng, P., Ding, H., Yang, H., Chen, W., Lin, H. and Chou, K.C. (2017) iRNA-PseColl: Identifying the Occurrence Sites of Different RNA Modifications by Incorporating Collective Effects of Nucleotides into PseKNC. Molecular Therapy—Nucleic Acids, 7, 155-163. https://doi.org/10.1016/j.omtn.2017.03.006

265. Cai, L., Huang, T., Su, J., Zhang, X., Chen, W., Zhang, F., He, L. and Chou, K.C. (2018) Implications of Newly Identified Brain eQTL Genes and Their Interactors in Schizophrenia. Molecular Therapy-Nucleic Acids, 12, 433-442. https://doi.org/10.1016/j.omtn.2018.05.026

266. Chen, W., Ding, H., Zhou, X., Lin, H. and Chou, K.C. (2018) iRNA(m6A)-PseDNC: Identifying N6-Methyladenosine Sites Using Pseudo Dinucleotide Composition. Analytical Biochemistry, 561-562, 59-65. https://doi.org/10.1016/j.ab.2018.09.002

267. Chen, W., Feng, P., Yang, H., Ding, H., Lin, H. and Chou, K.C. (2018) iRNA-3typeA: Identifying 3-Types of Modification at RNA's Adenosine Sites. Molecular Therapy—Nucleic Acids, 11, 468-474.

https://doi.org/10.1016/j.omtn.2018.03.012

268. Su, Z.D., Huang, Y., Zhang, Z.Y., Zhao, Y.W., Wang, D., Chen, W., Chou, K.C. and Lin, H. (2018) iLoc-lncRNA: Predict the Subcellular Location of lncRNAs by Incorporating Octamer Composition into General PseKNC. Bioinformatics, 34, 4196-4204. https://doi.org/10.1093/bioinformatics/bty508

269. Yang, H., Qiu, W.R., Liu, G., Guo, F.B., Chen, W., Chou, K.C. and Lin, H. (2018) iRSpot-Pse6NC: Identifying Recombination Spots in Saccharomyces cerevisiae by Incorporating Hexamer Composition into General PseKNC. International Journal of Biological Sciences, 14, 883-891. https://doi.org/10.7150/ijbs.24616

270. Feng, P., Yang, H., Ding, H., Lin, H., Chen, W. and Chou, K.C. (2019) iDNA6mA-PseKNC: Identifying DNA $\mathrm{N}^{6}$-Methyladenosine Sites by Incorporating Nucleotide Physicochemical Properties into PseKNC. Genomics, 
111, 96-102. https://doi.org/10.1016/j.ygeno.2018.01.005

271. Chou, K.C. and Elrod, D.W. (1998) Using Discriminant Function for Prediction of Subcellular Location of Prokaryotic Proteins. Biochemical and Biophysical Research Communications (BBRC), 252, 63-68. https://doi.org/10.1006/bbrc.1998.9498

272. Chou, K.C. and Elrod, D.W. (1999) Protein Subcellular Location Prediction. Protein Engineering, Design and Selection, 12, 107-118. https://doi.org/10.1093/protein/12.2.107

273. Chou, K.C. and Elrod, D.W. (1999) Prediction of Membrane Protein Types and Subcellular Locations. Proteins. Structure, Function, and Bioinformatics, 34, 137-153. https://doi.org/10.1002/(SICI)1097-0134(19990101)34:1<137::AID-PROT11>3.0.CO;2-O

274. Chou, K.C. (2000) Prediction of Protein Structural Classes and Subcellular Locations. Current Protein and Peptide Science, 1, 171-208. https://doi.org/10.2174/1389203003381379

275. Chou, K.C. (2000) Prediction of Protein Subcellular Locations by Incorporating Quasi-Sequence-Order Effect. Biochemical and Biophysical Research Communications (BBRC), 278, 477-483. https://doi.org/10.1006/bbrc.2000.3815

276. Cai, Y.D., Liu, X.J., Xu, X.B. and Chou, K.C. (2002) Support Vector Machines for Prediction of Protein Subcellular Location by Incorporating Quasi-Sequence-Order Effect. Journal of Cellular Biochemistry, 84, 343-348. https://doi.org/10.1002/jcb.10030

277. Cai, Y.D. and Chou, K.C. (2003) Nearest Neighbour Algorithm for Predicting Protein Subcellular Location by Combining Functional Domain Composition and Pseudo Amino Acid Composition. Biochemical and Biophysical Research Communications (BBRC), 305, 407-411. https://doi.org/10.1016/S0006-291X(03)00775-7

278. Chou, K.C. and Cai, Y.D. (2003) Prediction and Classification of Protein Subcellular Location: Sequence-Order Effect and Pseudo Amino Acid Composition. Journal of Cellular Biochemistry, 90, 1250-1260. (Addendum, ibid. 2004, 91, 1085) https://doi.org/10.1002/jcb.10719

279. Chou, K.C. and Cai, Y.D. (2004) Prediction of Protein Subcellular Locations by GO-FunD-PseAA Predictor. Biochemical and Biophysical Research Communications (BBRC), 320, 1236-1239. https://doi.org/10.1016/j.bbrc.2004.06.073

280. Gao, Y., Shao, S.H., Xiao, X., Ding, Y.S., Huang, Y.S., Huang, Z.D. and Chou, K.C. (2005) Using Pseudo Amino Acid Composition to Predict Protein Subcellular Location: Approached with Lyapunov Index, Bessel Function, and Chebyshev Filter. Amino Acids, 28, 373-376. https://doi.org/10.1007/s00726-005-0206-9

281. Xiao, X., Shao, S., Ding, Y., Huang, Z., Huang, Y. and Chou, K.C. (2005) Using Complexity Measure Factor to Predict Protein Subcellular Location. Amino Acids, 28, 57-61. https://doi.org/10.1007/s00726-004-0148-7

282. Chou, K.C. and Shen, H.B. (2006) Predicting Protein Subcellular Location by Fusing Multiple Classifiers. Journal of Cellular Biochemistry, 99, 517-527. https://doi.org/10.1002/jcb.20879

283. Chou, K.C. and Shen, H.B. (2006) Predicting Eukaryotic Protein Subcellular Location by Fusing Optimized Evidence-Theoretic K-Nearest Neighbor Classifiers. Journal of Proteome Research, 5, 1888-1897. https://doi.org/10.1021/pr060167c

284. Xiao, X., Shao, S.H., Ding, Y.S., Huang, Z.D. and Chou, K.C. (2006) Using Cellular Automata Images and Pseudo Amino Acid Composition to Predict Protein Subcellular Location. Amino Acids, 30, 49-54. https://doi.org/10.1007/s00726-005-0225-6

285. Chou, K.C. and Shen, H.B. (2007) Euk-mPLoc: A Fusion Classifier for Large-Scale Eukaryotic Protein Subcellular Location Prediction by Incorporating Multiple Sites. Journal of Proteome Research, 6, 1728-1734. https://doi.org/10.1021/pr060635i

286. Chou, K.C. and Shen, H.B. (2007) Recent Progresses in Protein Subcellular Location Prediction. Analytical Bio- 
chemistry, 370, 1-16. https://doi.org/10.1016/j.ab.2007.07.006

287. Wan, S.B., Hu, L.L., Niu, S., Wang, K., Cai, Y.D. and Chou, K.C. (2011) Identification of Multiple Subcellular Locations for Proteins in Budding Yeast. Current Bioinformatics, 6, 71-80.

288. Chou, K.C., Wu, Z.C. and Xiao, X. (2012) iLoc-Hum: Using Accumulation-Label Scale to Predict Subcellular Locations of Human Proteins with Both Single and Multiple Sites. Molecular BioSystems, 8, 629-641.

https://doi.org/10.1039/C1MB05420A 